\title{
A Comparison of In-flight Refueling Methods for Fighter Aircraft: Boom-receptacle vs. Probe-and-drogue
}

\author{
Brian J. Theiss \\ Embry-Riddle Aeronautical University
}

\begin{abstract}
Aerial refueling dates back to the very beginnings of flight and has developed into two very different and incompatible methods. While the U.S. Air Force primarily uses a boom-receptacle method, the U.S. Navy uses a probe-and-drogue method. Cross-service commonality of aerial refueling methods is a concept that has the potential to save money and increase the tactical abilities of the armed services. This paper serves to examine the feasibility of using a common method of aerial refueling for fighter/attack aircraft (collectively referred to as fighter aircraft). Safety, reliability, weight and refuel rates have been examined for each method. Currently there can be no set standard for fighter aircraft. The requirements for the U.S. Navy are such that they would not be able to utilize boom-receptacle refueling adequately, and similarly the requirements for the U.S. Air Force are such that probe-and-drogue refueling would not be feasible. There are many variables to consider with each aircraft and its intended use that affect which method is best incorporated.
\end{abstract}

\section{INTRODUCTION}

Currently, there are two different and incompatible methods for aerial refueling. The first method is a probe-and-drogue method used by the United States Navy, Marine Corps, and limited United States Air Force aircraft. The aircraft requiring fuel is equipped with a probe that extends forward from the aircraft. The pilot must maneuver to insert the probe into a basket or drogue that trails from the tanker aircraft to obtain fuel and then must disconnect when the operation is complete (Smith, 1998). The second method is a boom-receptacle method used by the United States Air Force. The aircraft requiring fuel is equipped with a receptacle while the tanker has a boom with control surfaces, better known as a flying boom. The aircraft requiring fuel is directed into place by the boom operator using director lights that are either manually or automatically activated. Once the aircraft is stable in the correct position, the boom operator inserts the boom into the receptacle and refuels the aircraft. Once refueling is complete, the boom operator withdraws the boom (Holder \& Wallace, 2000). Tankers with only a flying boom, like many $\mathrm{KC}$ 135 s, can use a boom-drogue adapter (BDA) kit that attaches to the boom as shown in Figure 1. Probe equipped aircraft can then refuel from the boom through the adapter. The limitation is that once the adapter is attached, the tanker can only refuel probe-equipped aircraft (Byrd, 1994). The BDA kit also has a greater tendency to snap off at the probe (Gebicke, 1993a). The Navy requires two drogues in the air for redundancy and that translates to two $\mathrm{KC}-135 \mathrm{~s}$ with adapter kits for Navy operations (Gebicke, 1993a). The $\mathrm{KC}-10$ has both a centerline drogue and a flying boom and therefore does not need an adapter kit. Still, without wingtip drogue pods for multiport refueling, there must be two $\mathrm{KC}-10 \mathrm{~s}$ in the air for Navy operations.

\section{HISTORY}

Aerial refueling dates back to World War I, when the need to extend aircraft range was realized. Frequent stops to refuel fighter aircraft are costly in terms of time and range and may not be feasible due to the weather. Alexander Seversky was a WWI pilot for the Imperial Russian Navy who immigrated to the United States and was the first person to apply for a patent on an aerial refueling system in 1921 (Byrd, 1994). The first refueling operation took place on November 12, 1921, when Wesley May climbed from a JN4 with a five gallon gas can strapped to his back (Holder \& Wallace, 2000). The first method that resembles aerial refueling of today was performed by dropping a fuel hose from one plane, while the pilot of the second 


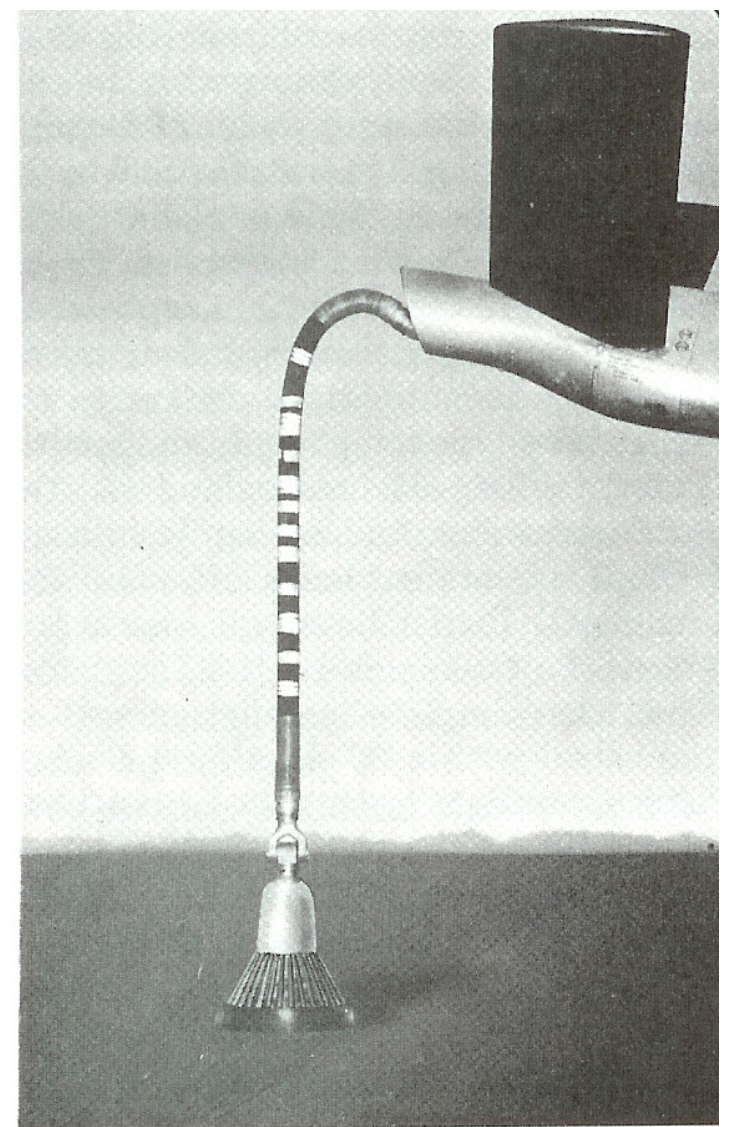

Figure 1. Boom-drogue adapter (BDA). Note. From Byrd, 1994 (p. 128).

plane reached out, grabbed the hose and refueled his plane in flight (Holder \& Wallace). This method proved quite dangerous and interest faded until 1942 when Col. Jimmy Doolittle wrote a letter to Major General Hap Arnold describing an aerial refueling concept (Holder \& Wallace). The Air Force Material Command (AMC) requested that Boeing conduct a study of air-to-air refueling. "Four months later, Boeing presented the results of its studies, outlining the possibilities of installing "hose-type" refueling equipment in both B-29 and B-50 bombers" (Holder \& Wallace, 2000, p. 13). Further research by Boeing brought about the flying boom (Byrd, 1994) while Britain's Flight Refueling Ltd. (FRL) developed the probe-anddrogue system (Byrd, 1994). During the Vietnam War, Air Force fighter airplanes such as the F-100 Super Saber were equipped with fixed refueling probes (Davis, 1986) and others, such as the F-105 Thunderchief, were equipped with both a retractable probe and a slipway (Drendel, 1986). Aircraft today are equipped with one or the other system, depending on the branch of service the aircraft is designed for. For example, the F-35 has an Air Force variant equipped with a slipway, while the Navy variant is equipped with a probe

\section{STATEMENT OF THE PROBLEM}

The problem is that U.S. Air Force (USAF) fighter aircraft and U.S. Navy (USN) fighter aircraft use two different and incompatible refueling methods. This study sought to find what the fuel transfer rates to fighter aircraft were for each method of aerial refueling, what the weight and volume impact on fighter aircraft was for aerial refueling equipment, and if there were safety or reliability concerns with either aerial refueling method.

There are very few fighter pilots who have had experience with both methods of aerial refueling, though their insights would prove most valuable. USAF boom operators have had experience with both methods, while USN aerial refueling crews have only had experience with the probe-and-drogue method. Much of the information regarding aerial refueling is considered sensitive since it details the capability and specifications of aircraft and their mission.

This study was limited to USAF tanker aircraft since they supply fuel for both USAF and USN fighter aircraft flown by the United States. Most other countries use the probe-anddrogue method exclusively and their input would add no additional insight to that of the USN. Examples may be used from other countries to make a point about tanker capability. Manufacturers of aerial refueling equipment were limited to those that have refueling equipment on USAF or USN fighter aircraft.

\section{REVIEW OF RELEVANT LITERATURE}

Two reports written by Mark E. Gebicke for the United States General Accounting Office (GAO) titled Aerial Refueling Initiative: CrossService Analysis Needed to Determine Best Approach (Gebicke, 1993a) and Operation Desert Storm: An Assessment of Aerial Refueling Operational Efficiency (Gebicke, 
1993b) stress the importance of multipoint refueling and suggest that Air Force fighter aircraft be equipped with probes and tankers be equipped with drogue baskets. Both reports were in response to a "request for an assessment of the performance of the air refueling tanker force during Operation Desert Storm" (Gebicke, 1993a, p. 1). The assessment was directed to analyze: (a) "the relevance, in light of that wartime experience, of a 1990 initiative to enhance tanker efficiency, effectiveness, and interoperability," and (b) "the adequacy of the Department of Defense assessment of the initiative" (Gebicke, 1993a, p. 1). "Essentially, the initiative called for standardizing Air Force refueling equipment for tankers and fighters on the probe/drogue refueling system" (Gebicke, 1993a, p. 1). Gebicke (1993b) actually states that the second point is to standardize the refueling systems of U.S. fighter aircraft.

One point made in Gebicke (1993a) is that "reasonable solutions to equipping F-16s and F22s with [probes] may exist" (p. 1). One option for mounting a probe on aircraft that were not produced with a refueling probe is the Aerial Refueling Tank System (ART/S) pod. The system is produced by Sargent Fletcher (a company under Flight Refueling Limited). The
ART/S pod is basically a drop tank with a retractable probe ("Sargent Fletcher", 2001). Gebicke (1993a) recognizes that at one time the Air Force used external probes where "the probe is bolted to the outside and covered with a second skin to smooth over the protrusion" ( $\mathrm{p}$. 6).

Gebicke (1993a) also states that "if the Air Force does not increase its participation in the initiative by adding probes to its fighters, it may not be cost-effective to add multipoint to both KC-10s and KC-135s for naval support" (p. 2). As shown in Figure 2 and Figure 3, operational multipoint systems have already been added to both the $\mathrm{KC}-10$ and the KC-135 tankers. Other countries have been able to refuel two probe aircraft and one slipway aircraft at the same time as shown in Figure 4.

As part of the background, Gebicke (1993b) states that "both the Marine Corps and the Navy must rely on the Air Force if extensive tanker support is required" (p. 2). The Navy has used the KA-6 Intruder as a tanker which has a maximum of 2,300 gallons of transferable fuel (Jenkins, 2002). The USAF and USMC KC-130 has $33,000 \mathrm{lbs}(5,076$ gallons $)$ of transferable fuel (Reed, 1999) while the USAF KC-135 has $200,000 \mathrm{lbs}(30,770$ gallons $)$ of transferable fuel



Figure 2. KC-10 multipoint. Note. From Steffen, 1998 (p. 112). 




Figure 3. KC-135 multipoint. Note. From Holder \& Wallace, 2000 (p. 135).

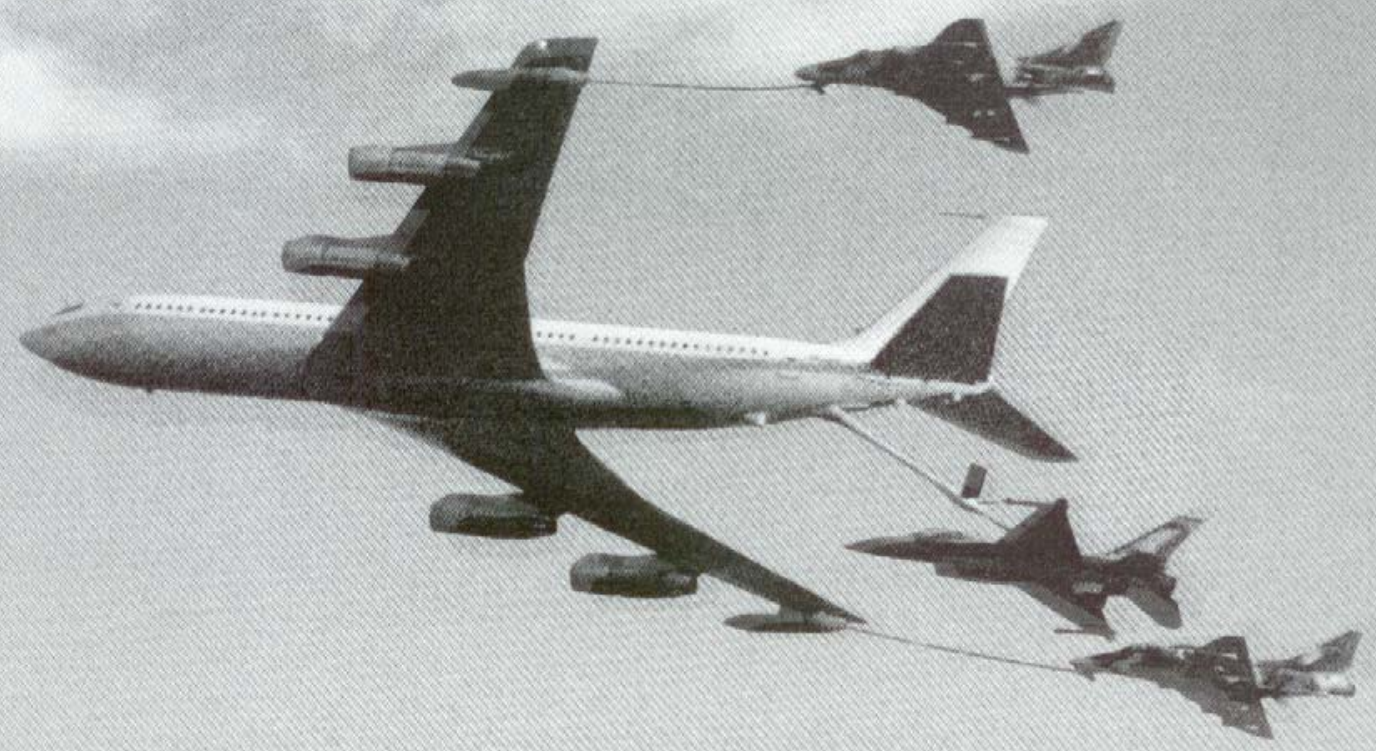

Figure 4. IAF multipoint. Note. From Holder \& Wallace, 2000 (p. 72).

("U.S. Air Force Fact Sheet: KC-135 Stratotanker," 2004) and the KC-10 has 356,000 lbs $(54,770$ gallons) of transferable fuel (Steffen, 1998). There was an attempt in 1963 to use the $\mathrm{KC}-130$ on a carrier but the KC-130 "was far too large for hangar stowage, and would have proved too difficult to integrate into normal operations with a full air wing embarked" (Reed,
1999). The F/A-18 Super Hornet has also been used as a Navy tanker but this would be a great misuse of an aircraft that was intended as an attack-fighter (Bolkcom \& Klaus, 2005).

Throughout both reports, Gebicke (1993a, 1993b) writes about the benefits of multipoint. "Since a multipoint tanker can transfer fuel more quickly, the tanker itself consumes less of its 
available fuel, leaving more fuel available for fighters" (Gebicke, 1993a, p. 7). "Since multipoint tankers have two off-load points, in these circumstances they would have been able to meet the tighter time constraints dictated by conventional operations with fewer tankers" (Gebicke, 1993b, p. 10).

Gebecke (1993a) recommends that "the Secretary of Defense reassess the aerial refueling initiative from a cross-service perspective with the primary goal of determining if probes should be added to Air Force fighters and how many multipoint tankers would be required to support Air Force and Naval operations" (Gebicke, 1993a, p. 17-18).

A similar report to Congress was written more recently by Bolkcom and Klaus (2005). In the introduction, it states that "a single hose-anddrogue can transfer between 1,500 and 2,000 lbs of fuel per minute," "today's fighter aircraft can accept fuel at 1,000 to 3,000 lbs per minute," and "the flying boom's primary advantage over the hose-and-drogue system is lost when refueling fighter aircraft" (Bolkcom \& Klaus, p. 2). Bolkcom and Klaus also state that "because KC-135 aircraft employ a single hose, Navy fighters must cycle six to eight aircraft through the refueling queue. By the time the last aircraft has refueled, the first one requires more gas" ( $p$.
3). F/A-18 Super Hornets have been used as tankers, but Bolkcom and Klaus state that "using these assets for aerial refueling rather than combat is seen as a sub-optimization of a scarce and valuable resource" (p. 4). Bolkcom and Klaus state that "seventy four percent of the [Air Force] fleet could potentially refuel with the [probe]-and-drogue with no reduction in fuel transfer rates" (p. 4). Bolkcom and Klaus described how the JSF and the F-22 Raptor with a refueling probe could replace the current inventory of Air Force fighter aircraft that have slipways. Bolkcom and Klaus discussed equipping tanker aircraft with booms versus equipping them with drogues. It is stated that the cost and complexity of the boom is greater than the drogue and the modifications are more significant. Bolkcom and Klaus state that "legacy USAF fighter aircraft would need to be retrofitted, and new aircraft would need to be manufactured with refueling probes if they were to exploit multipoint [probe]-and-drogue refueling" (p. 6).

There is a wing mounted probe that has been tested but is not operational. Figure 5 shows a drawing by Dexter Kalt (advisor to the board of directors of ARSAG) depicting the Universal Aerial Refueling Store.



Figure 5. Universal aerial refueling store. Note. From Holder \& Wallace, 2000 (p. 37). 
"This technique was tested on a KC-135, and it performed well. Receiver aircraft noted the lack of turbulence since there was less turbulence around the wings than the fuselage. The system was operated remotely" (Holder \& Wallace, 2000, p. 37). Bolkcom and Klaus (2005) cite five studies and state that "all found that tankers equipped with multipoint hose-anddrogue refueling would refuel combat aircraft more effectively than boom equipped aircraft" (p. 7). One of the reports cited by Bolkcom and Klaus is the Aerial Refueling Initiative (Gebecke, 1993a).

Bolkcom and Klaus (2005) argue in support of flying booms. "A tanker with a flying boom can be converted in the field to accommodate probe-equipped aircraft, if necessary. [Probe]and-drogue tankers cannot be converted to accommodate aircraft with boom receptacles. To accommodate fighter aircraft, tankers with flying booms can reduce the speed at which they dispense fuel. Tankers with [probe]-and-drogue refueling cannot increase the speed at which they dispense fuel to accommodate bombers and other large aircraft" (Bolkcom \& Klaus, p. 8).

Smith (1998) provides an historical account of aerial refueling. One section of the piece is titled Boom Versus Probe-and-Drogue Refueling. This section explains the influence of the Strategic Air Commander, General Curtis E. LeMay, who did not approve of the probeand-drogue method. "Probe-and-drogue involved a lot of rubber, a material that could become unreliable in the $-60^{\circ} \mathrm{F}$ temperatures above 30,000 feet" (p. 41). "During February 47, 1951, a fly-off between the probe-and-drogue and the Boeing boom conducted at Offutt AFB, Nebraska, produced predictable results. Pilots of small maneuverable airplanes liked probeand-drogue; those who flew big airplanes preferred the boom" (p. 41-43). "Headquarters United States Air Force finally settled this issue on July 14, 1958, when it announced that boom refueling would be the standard for its airplanes" (p. 43).

Killingsworth (1996) reviewed five past studies to determine whether any general conclusions could be drawn. "Advocates of a transition to multipoint aerial refueling describe multipoint benefits as follows: greater flexibility and interoperability of U.S. forces, and the possibility of budgetary savings resulting from the smaller tanker inventory that could be required" (p. vii). Killingsworth is published by the RAND Corporation, a nonprofit institution that helps improve policy and decision making through research and analysis ("RAND Mission", 2005). Killingsworth reviewed a RAND study from 1990. "The study helped to focus on probe/drogue technology as an alternative with potential to enhance tanker force effectiveness" (p. vii). "As recommended by the RAND work, the Air Force in 1991 and 1992 conducted its own studies of the cost effectiveness of multipoint. Some of the assumptions made by the Air Force Studies and Analyses Agency (AFSAA) in these studies were less favorable to multipoint than those used by RAND. In particular, AFSAA used higher overall fuel transfer rates, as well as relatively higher rates for transfers using the boom/receptacle than using the probe/drogue transfers" (Killingsworth, p. vii-viii). "In 1993, the Air Mobility Command (AMC) conducted a study of the numbers of multipoint-equipped tankers needed to support Navy carrier-based operations during a contingency." "The AMC study showed little advantage to having multipoint-equipped tankers" (Killingsworth, p. viii). Killingsworth conducted a contingency analysis for the Gulf War focusing on the 32nd day after the start of the war because he was looking for a boom-limited situation or a situation in which multipoint would have made possible the use of fewer tankers or the refueling of more fighters. "Of 214 tanker sorties flown on that day, only 21 could have been deleted by combining fighter packages behind fewer tankers. Further analysis indicates that only one of these combinations would actually have required multipoint capability" (Killingsworth, p. x). Killingsworth continues with observations on fighter retrofits, "a program to retrofit large numbers of current U.S. fighters with probes is probably inadvisable, but the apparent advantages of multipoint aerial refueling indicate that the installation of probes on followon fighter aircraft should be considered" (pp. xxi). 


\section{RESEARCH QUESTIONS}

Based on the review of literature, the following six research questions were proposed for this study.

1. What is the fuel transfer rate of the boomreceptacle method of aerial refueling?

2. What is the fuel transfer rate of the probeand-drogue method of aerial refueling?

3. What is the weight and volume impact of a refueling receptacle on fighter aircraft?

4. What is the weight and volume impact of a refueling probe on fighter aircraft?

5. Are there safety or reliability concerns with a boom-receptacle method of aerial refueling?

6. Are there safety or reliability concerns with a probe-and-drogue method of aerial refueling?

\section{METHODOLOGY}

This research was a descriptive study, focused on historical data. Data was requested from aerial refueling wings, USAF and USN fighter pilots, and manufacturers of aerial refueling equipment. Information from aerial refueling wings was requested to answer questions about refuel rates and equipment reliability concerns. Fighter pilots were asked to supply information about refuel rates and equipment reliability concerns. Manufacturers of aerial refueling equipment were asked to supply information about equipment weight and volume and refueling flow rates.

The survey population for aerial refueling wings or groups is listed in Appendix A. There were 15 aerial refueling units. The survey population of fighter pilots was all active and retired fighter pilots that have performed aerial refueling. The first method of sampling fighter pilots was to ask current and former pilots whom I was in contact with to fill out the survey and pass it along to others. The second method was to send the form to USAF and USN fighter squadrons and request that pilots fill out the form. The sample size is all surveys that were returned. The only known manufacturers of aerial refueling equipment were Sargent Fletcher and Parker Hannifin Corporation.
For the Aerial Refueling Wing Survey, aerial refueling wings were asked to supply information about fuel transfer rates and safety or reliability concerns for their operations since 1998. For the Fighter Pilot Survey, fighter pilots were asked to supply information about fuel transfer rates and safety or reliability concerns during their aerial refueling experiences. Manufacturers of aerial refueling equipment were asked to supply information about fuel transfer rates and weight and volume impacts of their products.

The first 10 questions on the Aerial Refueling Wing Survey addressed the transfer rates of fuel to fighter aircraft. This included the amount of time it takes to connect and to disconnect. Questions 11 and 12 addressed the reliability and safety of each refueling system. Questions 13 through 15 were general questions that augmented the research questions. Question 16 was related to the research question of refueling rates. Questions 17 and 18 related to aerial refueling safety and reliability.

Questions 1 and 2 of the Fighter Pilot Survey were demographic questions regarding the background of the fighter pilots. Questions 3 and 4 addressed the safety and reliability research questions. Question 5 addressed research questions on refuel rates. Questions 6 and 7 concerned factors that might influence refuel rates. Question 8 addressed preference for a particular refueling method. Question 9 was a qualitative question asking for amplifying research information.

The Aerial Refueling Wing Survey was valid, since the information came from the people who operate the tanker refueling equipment. Information from aerial refueling equipment manufacturers was valid because the companies design and create the equipment for a specific range of fuel flow rates and to fit in a specific volume with a specific weight.

Consistent results depended on similarity among the items that make up the two independent constructs of the surveys, safety or reliability concerns and the fuel transfer rate. Two questions in the fighter pilot survey were developed to evaluate safety and reliability concerns and three questions were developed to evaluate fuel transfer rates. Eleven questions in the refueling wing survey were developed to 
evaluate fuel transfer rates, and correlation coefficients among each of these questions were calculated to assess the internal consistency of each construct in the survey.

Descriptive statistics were used to describe each of the variables collected in the surveys. Data from the first two questions in the fighter pilot survey, type of aircraft flown, flight hours and aerial refueling method (Question 1) and number of aerial refuelings (Question 2), were described by tables depicting the number of responses and totals for each question. Responses to number of refueling incidents (Question 4), time required to refuel four aircraft (Question 5), and which system is preferred (Question 8) in the fighter pilot survey were described by tables depicting totals and percentages for each question.

Data from the first five questions in the aerial refueling wing survey, time considerations for refueling operations, were described by a table depicting the averages for each question and the total for the five questions. Responses to the number of aircraft refueled (Question 6), the mission time (Question 7), missions per flight (Question 8), flow rate (Question 9), and fuel amount transferred (Question 10) in the aerial refueling wing survey were described by a table depicting the averages for each question. Responses to the question regarding the receiver or tanker being fouled (Question 11), mechanical failures (Question 12), other aircraft being refueled on the same mission (Question 13 and Question 14) and multi-port (Question 15) were described by a table depicting percentages for each question. Responses to the questions regarding which method the respondent thought was faster (Question 16), which was safer (Question 17) and which was more reliable (Question 18) were described by a table depicting the fractional preference for each method.

Data from manufacturers and additional sources were described by tables depicting the information collected.

The qualitative responses were evaluated and themes created to identify any noted barriers that could be resolved to facilitate acceptance of one aerial refueling method. Selected qualitative responses were used to clarify and enrich the discussion and conclusions of the study.

\section{RESULTS}

Fighter Pilot Survey Results

Thirty-one fighter pilots responded to the fighter pilot survey (Appendix B). Each pilot was given a number from 1 to 31 in no specific order. Table 1 shows the responses from Question 1, the method of aerial refueling the respondents have used.

Table 1. Fighter Pilot Refueling Methods

\begin{tabular}{lcc}
$\begin{array}{c}\text { Respondent's } \\
\text { aerial refueling } \\
\text { method }\end{array}$ & $\begin{array}{c}\text { Number of } \\
\text { respondents }\end{array}$ & $\begin{array}{c}\text { Percentage } \\
\text { of } \\
\text { respondents }\end{array}$ \\
\hline $\begin{array}{l}\text { Probe-and- } \\
\text { drogue only }\end{array}$ & 6 & $19 \%$ \\
$\begin{array}{l}\text { Boom- } \\
\text { receptacle only }\end{array}$ & 18 & $58 \%$ \\
Both & 7 & $23 \%$ \\
Total & 31 & $100 \%$ \\
\hline
\end{tabular}

Table 2 shows the total hours the pilots have flown with respect to the method of aerial refueling the aircraft is capable of (also from Question 1). Two fighter pilots did not state how many hours they had flown and one pilot did not specify which method was used in an aircraft that could have refueled either way.

Table 2. Fighter Pilot Flight Hours

\begin{tabular}{lcc}
\hline $\begin{array}{c}\text { Respondent's } \\
\text { aerial refueling } \\
\text { method }\end{array}$ & $\begin{array}{c}\text { Flight } \\
\text { hours in } \\
\text { type }\end{array}$ & $\begin{array}{c}\text { Percentage } \\
\text { of total } \\
\text { respondents }\end{array}$ \\
\hline $\begin{array}{l}\text { Probe-and- } \\
\text { drogue }\end{array}$ & 19,870 & $26 \%$ \\
$\begin{array}{l}\text { Boom- } \\
\text { receptacle }\end{array}$ & 54,690 & $72 \%$ \\
Not specified & 1,500 & $2 \%$ \\
Total & 76,060 & $100 \%$ \\
\hline
\end{tabular}

Table 3 shows responses from Question 2 regarding how many aerial refueling operations the respondents have performed during training, deployments and combat as well as totals for each method and situation. 
Table 3. Number of Aerial Refueling Operations

\begin{tabular}{lllll}
\hline & Training & Deployment & Combat & Total \\
\hline Probe-and- & 2,410 & 1,106 & 285 & 3,801 \\
Boom- & 5,874 & 1,771 & 1,332 & 8,977 \\
Either & 50 & 100 & 10 & 160 \\
Total & 8,334 & 2,977 & 1,627 & 12,938 \\
\hline
\end{tabular}

Table 4. Probe-and-drogue Aerial Refueling Incidents

KC-130 low altitude tanking turbulence damaged FA-18 probe tip.

$\mathrm{KC}-135$ hose whip from BDA damaged FA-18 probe tip.

Near mid-air due to other fighter flying with night vision lights on.

Hydraulic failure in drogue hose causing probe and/or drogue damage.

Fuel leaking from probe/drogue connection.

Drogue failed to extend.

Drogue failed to pump fuel.

Basket slaps (drogue slaps receiver aircraft).

KC-130 reel response failure.

F-100 probe snapped off.

Table 5. Boom-receptacle Aerial Refueling Incidents

FOD from tanker (KC-135 lights falling, KC-135 antenna wire).

Near mid-air ( 2 tankers plus one receiver / 2 formations plus one tanker).

Failure of boom latches in the receptacle to grasp boom tip and hold under pressure.

Pump malfunctions - reduced flow rate or no flow.

Spatial disorientation.

Tanker autopilot turning off while on boom.

Brute force disconnects. 
Table 4 contains answers to Question 3 detailing some incidents that occurred during probe-and-drogue aerial refueling, while Table 5 contains answers detailing incidents that occurred during boom-receptacle aerial refueling.

Table 6 shows responses to Question 4, how many times there was a mission change due to an aerial refueling incident, coupled with responses to Question 2, the number of aerial refueling operations.

Table 6. Aerial Refueling Incidents

\begin{tabular}{lccc}
\hline Method & $\begin{array}{c}\text { Mission } \\
\text { change } \\
\text { incidents } \\
(\mathrm{Q} 4)\end{array}$ & $\begin{array}{c}\text { Total } \\
\text { refueling } \\
\text { operations } \\
(\mathrm{Q} 2)\end{array}$ & $\begin{array}{c}\text { Percentage } \\
\text { of } \\
\text { incidents }\end{array}$ \\
\hline $\begin{array}{l}\text { Probe- } \\
\text { and- } \\
\text { drogue }\end{array}$ & 49 & 2,925 & $1.7 \%$ \\
$\begin{array}{l}\text { Boom- } \\
\text { receptacle }\end{array}$ & 195 & 6,003 & $3.2 \%$ \\
$\begin{array}{l}\text { Either } \\
\text { Total }\end{array}$ & 15 & 4,010 & $0.4 \%$ \\
\hline
\end{tabular}

Table 7 shows the responses to Question 5 about the fuel transfer rate for four aircraft. Also in Table 7 are answers to Question 6, 7 and
8, about multi-port, quick flow and buddy store. Where "N/A" is listed, the operation is not currently applicable to that method of aerial refueling.

Table 7. Fuel Transfer Rate

\begin{tabular}{lllll}
\hline Method & $\begin{array}{l}\text { 4-Ship } \\
\text { transfer } \\
\text { time } \\
\text { (minutes) } \\
\text { (Q5) }\end{array}$ & $\begin{array}{l}\text { Multi- } \\
\text { port } \\
\text { (Q6) }\end{array}$ & $\begin{array}{l}\text { Buddy } \\
\text { store } \\
\text { (Q7) }\end{array}$ & $\begin{array}{l}\text { Quick } \\
\text { flow } \\
\text { (Q8) }\end{array}$ \\
\hline $\begin{array}{l}\text { Probe- } \\
\text { and- } \\
\text { drogue }\end{array}$ & 20.9 & $24 \%$ & $18 \%$ & N/A \\
$\begin{array}{l}\text { Boom- } \\
\text { receptacle }\end{array}$ & 19.6 & N/A & N/A & $10 \%$ \\
\hline
\end{tabular}

Table 8 shows responses to Question 9, which aerial refueling method is preferred. Pilots who have had experience with both methods of aerial refueling have been listed as "Dual Method Pilots."

\section{Aerial Refueling Wing Survey Results}

Of the 15 surveys that were sent to each aerial refueling wing (Appendix C), four replied. Table 9 shows responses that were supplied by the four refueling wings for the first 5 questions which concerned the amount of time it takes to refuel an aircraft.

Table 8. Fighter Pilot Preferred Method

\begin{tabular}{lllll}
\hline \multicolumn{1}{c}{ Group } & Preference? & Preference & Number & Percentage \\
\hline All Respondents & Yes & Boom-Receptacle & 13 & $41.9 \%$ \\
& & Probe-and-Drogue & 5 & $16.1 \%$ \\
& No & & 13 & $41.9 \%$ \\
\hline Dual Method Pilots & Yes & Boom-Receptacle & 5 & $71.4 \%$ \\
& & Probe-and-Drogue & 1 & $14.3 \%$ \\
& No & & 1 & $14.3 \%$ \\
\hline
\end{tabular}


Table 9. Time to Refuel Aircraft

\begin{tabular}{lcc}
\hline & $\begin{array}{c}\text { Probe-and- } \\
\text { drogue }\end{array}$ & $\begin{array}{c}\text { Boom- } \\
\text { receptacle }\end{array}$ \\
\hline $\begin{array}{l}\text { Line up } \\
\text { (seconds) }\end{array}$ & 90.0 & 90.0 \\
\hline $\begin{array}{l}\text { Hook up } \\
\text { (seconds) }\end{array}$ & 85.0 & 40.8 \\
\hline $\begin{array}{l}\text { Transfer fuel } \\
\text { (seconds) }\end{array}$ & 420.0 & 300.0 \\
\hline $\begin{array}{l}\text { Disconnect } \\
\text { (seconds) }\end{array}$ & 3.8 & 2.3 \\
\hline Clear (seconds) & 8.3 & 8.3 \\
\hline Total (seconds) & 607.2 & 441.5 \\
\hline Total (1 ship) & $\begin{array}{c}\text { 10 minutes } \\
7 \text { seconds }\end{array}$ & $\begin{array}{c}7 \text { minutes } \\
\text { seconds }\end{array}$ \\
\hline
\end{tabular}

Table 10 shows responses from the four aerial refueling wings on Questions 6 through 10 on factors that affect or are affected by the amount of time it takes to refuel fighter aircraft.

\begin{tabular}{|c|c|c|}
\hline & $\begin{array}{c}\text { Probe-and- } \\
\text { drogue }\end{array}$ & $\begin{array}{c}\text { Boom- } \\
\text { receptacle }\end{array}$ \\
\hline $\begin{array}{l}\text { Number of AC } \\
\text { refueled }\end{array}$ & 2 & 2 \\
\hline $\begin{array}{l}\text { Mission time } \\
\text { (minutes) }\end{array}$ & 13.0 & 11.7 \\
\hline $\begin{array}{l}\text { Missions per } \\
\text { flight }\end{array}$ & 1 & 1 \\
\hline $\begin{array}{l}\text { Flow rate } \\
\text { (lbs/min) }\end{array}$ & 791.8 & $1,291.9$ \\
\hline $\begin{array}{l}\text { Fuel amount } \\
\text { (lbs) }\end{array}$ & $13,833.3$ & $13,833.3$ \\
\hline
\end{tabular}

Table 11 summarizes the responses given to Questions 11 through 15 which address safety, reliability, and factors that affect aerial refueling operations.
Table 11. Safety, Reliability, and Operational Refueling Factors

\begin{tabular}{lcc}
\hline & $\begin{array}{c}\text { Probe-and- } \\
\text { drogue }\end{array}$ & $\begin{array}{c}\text { Boom- } \\
\text { receptacle }\end{array}$ \\
\hline $\begin{array}{l}\text { Receiver or } \\
\text { tanker fouled }\end{array}$ & $7.2 \%$ & $2.0 \%$ \\
\hline $\begin{array}{l}\text { Mechanical } \\
\text { failure }\end{array}$ & $3.3 \%$ & $2.0 \%$ \\
\hline $\begin{array}{l}\text { Fighter }+ \\
\text { helicopter }\end{array}$ & $0.0 \%$ & $0.0 \%$ \\
\hline Fighter + cargo & $0.3 \%$ & $0.3 \%$ \\
\hline Multi-port & $3.3 \%$ & $0.0 \%$ \\
\hline
\end{tabular}

Table 12 shows responses to Questions 16 through 18 , which method of aerial refueling is preferred by the respondents.

Table 12. ARW Preferred Method

\begin{tabular}{lcc}
\hline & $\begin{array}{c}\text { Probe- } \\
\text { and- } \\
\text { drogue }\end{array}$ & $\begin{array}{c}\text { Boom- } \\
\text { receptacle }\end{array}$ \\
\hline 16. Which is faster? & 0 & 4 \\
\hline 17. Which is safer? & 0 & 4 \\
\hline $\begin{array}{l}\text { 18. Which is more } \\
\text { reliable? }\end{array}$ & 0 & 4 \\
\hline
\end{tabular}

Aerial Refueling Wing Activity

The fifteen aerial refueling wings were asked to supply information regarding aerial refueling operations under the Freedom of Information Act (FOIA). Five aerial refueling wings replied to the request. Each refueling wing was given a number 1 through 5 in no specific order. There were no responses to the request for fuel transfer rates because fuel transfer rates (pounds/minute) and the time it takes to transfer fuel (minutes) are not tracked by the aerial refueling wings. Aerial refueling wings do track the type of aircraft refueled and the amount of fuel transferred. From the type of aircraft refueled, it can be discerned what aerial refueling method was used. Table 13 shows a summary of the responses. ARW number 1 supplied a conversion for fuel at 1 gallon $=6.8$ lbs. 
Table 13. Aircraft Refueled by USAF Aerial Refueling Wings

\begin{tabular}{lll}
\hline & Probe-and-drogue & Boom-receptacle \\
\hline Total aircraft & 103 & 1,595 \\
Percentage of aircraft & $6.1 \%$ & $93.9 \%$ \\
Total offload & $695,200 \mathrm{lbs}$ & $11,678,820 \mathrm{lbs}$ \\
Percentage of offload & $5.6 \%$ & $94.4 \%$ \\
Average offload & $6,750 \mathrm{lbs}(993 \mathrm{Gal})$ & $7,322 \mathrm{lbs}(1,077 \mathrm{Gal})$ \\
\hline
\end{tabular}

In response to the request for whether any incidents occurred to damage equipment or interrupt the refueling mission, one aerial refueling wing stated that no incidents damaged any aircraft or interrupted any missions. Two aerial refueling wings supplied maintenance records, but it could not be discerned whether any maintenance was required due to an aerial refueling incident or if any aerial refueling mission was altered due to equipment malfunction.

Manufacturer Aerial Refueling Information

Table 14 ("Sargent Fletcher," 2005) shows fuel flow rates for some of the Sargent Fletcher products. These are all tanker delivery systems and weights of the products do not affect the fighter receiver.

Table 14. Fuel Flow Rates For Sargent Fletcher Products

\begin{tabular}{|c|c|c|}
\hline System & Part No. (Model) & Fuel Flow (GPM) \\
\hline \multirow{3}{*}{ Buddy-Store } & $28-300-48116$ & 200 \\
\hline & $31-300-48310$ & 200 \\
\hline & $31-301-48310$ & 220 \\
\hline \multirow{8}{*}{ Hose-Reel } & 149R1001(FR300 B, D, E, F) & $150-330$ \\
\hline & 149R1051 (FR300 C) & $150-330$ \\
\hline & 230-101 (FR300 K) & $150-330$ \\
\hline & 149R1001-118 (FR & $150-330$ \\
\hline & 208-1001 (FR400) & 400 \\
\hline & 233-1001 (FR480) & 450 \\
\hline & 227-1004 (FR500) & 500 \\
\hline & 224-1070 (FR600) & 600 \\
\hline \multirow{2}{*}{ Wing-Mounted Pod } & $34-000-48317$ & 400 \\
\hline & $48-000-4862$ & $150-330$ \\
\hline
\end{tabular}

Note. From www.sargentfletcher.com/ars_charact.htm 
Parker Aerospace, a division of Parker Hannifin Corporation produces probe equipment as well as receptacle equipment. The probe tip (nozzle) model MA-2 supplied by Parker aerospace weighs a maximum of 18.0 pounds ("Parker Aerospace," 2004). No other data was supplied by the Parker Hannifin Corporation including weight, volume and flow rate data for receptacles.

\section{Additional Sources}

The USN trains fighter pilots in the use of many different tanker platforms. One manual used to brief pilots on aerial refueling is the Naval Air Training and Operating Procedures Standardization Program (NATOPS) Air Refueling Manual. Table 15 shows flow rates that are to be expected from various platforms (Naval Air Training, 1985).

Table 15. NATOPS Probe-and-drogue Aerial Refueling Rates

\begin{tabular}{|c|c|c|c|}
\hline Platform & Comments and/or Conditions & $\begin{array}{l}\text { Max Flow } \\
\text { Rate }\end{array}$ & Typical Flow Rate \\
\hline $\begin{array}{c}\mathrm{D}-704 \\
\text { (Buddy-Store) }\end{array}$ & Used on F-4, A-4, A-6, and A-7 aircraft. & 180 GPM & \\
\hline \multirow[t]{3}{*}{ KC-130 } & With 2 removable 3,600 gal tanks and both & $600 \mathrm{GPM}$ & \\
\hline & With one pump used & $300 \mathrm{GPM}$ & \\
\hline & Only wing store fuel available & $150 \mathrm{GPM}$ & \\
\hline KA-3B & & $420 \mathrm{GPM}$ & \\
\hline KA-6 & & $350 \mathrm{GPM}$ & \\
\hline $\mathrm{KC}-10$ & $\begin{array}{l}\text { Depending on the specific receiver and the } \\
\text { number of pumps operating }\end{array}$ & $600 \mathrm{GPM}$ & 100-500 GPM \\
\hline KC-135 & $\begin{array}{l}\text { CAUTION: There is no hose response with } \\
\text { this system. }\end{array}$ & \multicolumn{2}{|c|}{$\begin{array}{l}\text { Governed by the fuel-flow capacity of } \\
\text { the receiver air refueling system. }\end{array}$} \\
\hline
\end{tabular}

One U.S. Government document that is used in the design of aerial refueling systems is the Joint Service Specification Guide (Department of Defense, 1998). Paragraph F.3.4.6.2.1.2 addresses receiver aerial refueling rates. Table 16 is a reduced table from the guidelines to show fighter aircraft only.

Table 16. Fighter Receiver Aerial Refueling Rates

\begin{tabular}{|c|c|c|}
\hline $\begin{array}{c}\text { Total Air } \\
\text { Vehicle Fuel } \\
\text { Weight (lb) }\end{array}$ & $\begin{array}{c}\text { Flow Rate } \\
- \\
\text { Referenced }\end{array}$ & $\begin{array}{c}\text { Time } \\
\text { (Minutes) } \\
\text { 90\% Load }\end{array}$ \\
\hline $10,000-25,000$ & 400 & $4-9$ \\
\hline UP TO- 10,000 & 300 & $\leq 5$ \\
\hline
\end{tabular}

\section{DISCUSSION}

Some of the fighter pilot surveys were completed with answers that need some clarification or correction. One pilot did not specify the method of aerial refueling but had 1,500 hours in an aircraft that could have refueled either way (the A-7 Corsair). This resulted in the "Not Specified" row in Table 2. Of the 54,690 hours of experience in receptacle equipped aircraft, 26,130 hours (48\%) are in the F-16. The pilot with the most flight hours had 5,600 hours with 1,000 hours in the A-7, 1,600 hours in the F-4 and 3,000 hours in the F-16, all of which refueled with the boom-receptacle method. Of the aircraft flown by the fighter pilots, there were nine different probe equipped aircraft, eight different receptacle aircraft and one aircraft where it was not specified which of the two possible methods was used. The F-105 also has both a probe and a receptacle but fighter pilot 17 specified that he refueled via the probe only in that aircraft. Fighter pilot 29 stated that he refueled via the probe on an A-10 aircraft, but the A-10 uses only a receptacle and has no provisions for a probe. The data for fighter pilot 
29 has been corrected in the results. Fighter pilot 13 flew the OA-37 which is an observation and attack aircraft that refuels with a probe and fighter pilot 5 flew the SR-71 which is a reconnaissance aircraft that refuels with a receptacle. Although not a fighter aircraft, the SR-71 was included to show other jet aircraft that the fighter pilots have flown that perform aerial refueling. One fighter pilot has flown the H-3, a helicopter, and one pilot has flown the S2 Tracker, a propeller driven submarine hunter, but neither aircraft is included in the results because they are too dissimilar from fighter aircraft.

There is a difference between Table 3 and Table 6 in the total number of refueling operations for each method of aerial refueling. This is because many of the pilots that have had experience with both methods of aerial refueling did not state how many incidents they experienced with each method of aerial refueling.

Most of the fighter pilots noted their estimate for the amount of time it took to refuel a flight of four aircraft. Thirteen pilots specified the receiver aircraft, one specified the tanker aircraft, fifteen did not specify either but gave an estimate and two pilots did not answer the question.

The top two reasons given to Question 9 of the fighter pilot survey for a preference in the probe-and-drogue method of aerial refueling were: (a) the fighter pilot is in control, and (b) tactical aircraft can be used as tankers (buddy store). As stated by Bolkcom and Klaus (2005), this would be a great misuse of an aircraft that was intended as an attack-fighter. The top two reasons given for a preference in the boomreceptacle method of aerial refueling were: (a) it is easier to fly, and (b) faster flow rate.

From Table 10, the only differences between probe-and-drogue and boom-receptacle aerial refueling were mission time and flow rate. The number of aircraft refueled, missions per flight and fuel amount transferred were the same for both types of aerial refueling.

Question 11 of the aerial refueling wing survey was a safety concern question that asked what percentage of refueling operations fouled the tanker or receiver system. The percentages of safety concern were $5.2 \%$ higher for the probe-and-drogue method than for the boomreceptacle method of aerial refueling. Question 12 was a reliability question that asked what percentage of refueling operations had a mechanical failure. The percentages of reliability concern were $1.3 \%$ higher for the probe-and-drogue method than for the boomreceptacle method of aerial refueling. Multi-port operation percentages were also higher for probe-and-drogue. Question 13 asked what percentage of missions refueled helicopters before or after fighter aircraft and one aerial refueling wing answered that $1 \%$ of boomreceptacle missions did. This is impossible because helicopters require the probe-anddrogue method. The data has been adjusted to zero for that response. Question 15 asked what percentage of refueling missions were multiport, and one aerial refueling wing answered that $8 \%$ of boom-receptacle missions were. Multiport is an option currently not available to the boom-receptacle method of aerial refueling. The data for this answer was also adjusted to zero.

\section{CONCLUSIONS}

The first two questions proposed for this study concern fuel transfer rates for each method of aerial refueling. From Table 7, the 4-ship transfer time for boom-receptacle aerial refueling is 19.6 minutes, or 4.9 minutes per ship. From Table 13, the average offload per boom-receptacle aircraft is $7,322 \mathrm{lbs}$. Dividing the offload per ship by the time per ship, gives $1,494.3 \mathrm{lbs} / \mathrm{min}$ (219.8 GPM) for boomreceptacle aerial refueling experienced by fighter pilots. From Table 7, the 4-ship transfer time for probe-and-drogue aerial refueling is 20.9 minutes, and multi-port was performed $24 \%$ of the time. If $24 \%$ of the time there were two aircraft refueling at the same time, it would be incorrect to assume that the time per ship is 5.2 minutes. Instead, Equation 1 shows how multiport affects the transfer time:

$$
\begin{aligned}
& 20.9 \mathrm{~min}=\frac{(X \cdot 76 \%)+\left(\frac{1}{2} X \cdot 24 \%\right)}{100 \%} \\
& \therefore X=23.75 \mathrm{~min}
\end{aligned}
$$


Now the per ship transfer time becomes 5.9 minutes for probe-and-drogue aerial refueling. From Table 13, the average offload per probeand-drogue aircraft is $6,750 \mathrm{lbs}$. Dividing the offload per ship by the time per ship, gives 1,144.1 $\mathrm{lbs} / \mathrm{min}$ (168.3 GPM) for probe-anddrogue aerial refueling experienced by fighter pilots.

From Table 9, the aerial refueling wing transfer time for probe-and-drogue aerial refueling is 420 seconds ( 7 minutes). From Table 11, 3.3\% of probe-and-drogue refueling operations are multi-port. The formula in Equation 2 shows how multi-port affects the transfer time:

$$
\begin{aligned}
& 7 \mathrm{~min}=\frac{(X \cdot 96.7 \%)+\left(\frac{1}{2} X \cdot 3.3 \%\right)}{100 \%} \\
& \therefore X=7.12 \mathrm{~min}
\end{aligned}
$$

The per ship transfer time is now 7.12 minutes. Dividing the offload per ship from Table 13 $(6,750 \mathrm{lbs})$ by the transfer time for probe-anddrogue aerial refueling, gives a refuel rate of $948.0 \mathrm{lbs} / \mathrm{min}$ (139.4 GPM). The aerial refueling wing transfer time for boom-receptacle aerial refueling is 300 seconds (5 minutes). Dividing the offload per ship from Table 13 $(7,322 \mathrm{lbs})$ by the transfer time for boomreceptacle aerial refueling, gives a refuel rate of 1,464.4 $\mathrm{lbs} / \mathrm{min}$ (215.4 GPM). The aerial refueling wings also supplied their estimates of the flow rates in Table 10. For probe-anddrogue the estimated flow rate is $791.8 \mathrm{lbs} / \mathrm{min}$ (116 GPM), and for boom-receptacle the estimated flow rate is $1,291.9 \mathrm{lbs} / \mathrm{min}$ (190 GPM).

The above figures that were experienced by fighter pilots and aerial refueling wings are low compared to what Sargent Fletcher advertises, as seen in Table 14 and what NATOPS expects, as seen in Table 15. For hose-reel systems, Sargent Fletcher advertises flow rates from 150 GPM (1020 lbs/min) on the low side to $600 \mathrm{GPM}$ (4080 $\mathrm{lbs} / \mathrm{min})$ on the high side. Similarly, NATOPS expects a typical flow rate from a KC10 to be between $100 \mathrm{GPM}(680 \mathrm{lbs} / \mathrm{min})$ and $500 \mathrm{GPM}$ (3400 lbs/min). Table 17 summarizes the findings for flow rates.

Table 17. Summary of Flow Rates

\begin{tabular}{lcccc}
\hline & \multicolumn{2}{c}{ Probe-and-drogue } & \multicolumn{2}{c}{ Boom-receptacle } \\
& $(\mathrm{lb} / \mathrm{min})$ & $(\mathrm{GPM})$ & $(\mathrm{lb} / \mathrm{min})$ & $(\mathrm{GPM})$ \\
\hline $\begin{array}{l}\text { Fighter pilots } \\
\text { Aerial refueling wings }\end{array}$ & $1,144.1$ & 168.3 & $1,494.3$ & 219.8 \\
(Table 9 \& Table 13) & & & & \\
(Table 10, Question 9) & 948.0 & 139.4 & $1,464.4$ & 215.4 \\
Sargent Fletcher & 791.8 & 116.4 & $1,291.9$ & 190.0 \\
High & & & & \\
Low & 4080.0 & 600 & & \\
NATOPS & 1020.0 & 150 & & \\
High & & & & \\
Low & $3,400.0$ & 500 & & \\
\hline
\end{tabular}


Table 18 shows the experienced flow rates as a percentile of Sargent Fletcher's advertised flow rates and the NATOPS expected flow rates. A negative number means that the experienced flow rate is lower than the lowest expected flow rate. This applies only to probe-and-drogue aerial refueling because there were no advertised or expected values associated with boomreceptacle aerial refueling exclusively.

Table 18. Experienced Flow Rates

\begin{tabular}{lcc}
\hline & $\begin{array}{c}\text { Percentile } \\
\text { of Sargent } \\
\text { Fletcher }\end{array}$ & $\begin{array}{c}\text { Percentile } \\
\text { of NATOPS }\end{array}$ \\
\hline Fighter pilots & 15 & 30 \\
\hline \multicolumn{2}{l}{ Aerial refueling wings } & \\
\hline $\begin{array}{l}\text { (Table 9 \& } \\
\text { Table 13) }\end{array}$ & -2 & 10 \\
\hline $\begin{array}{l}\text { (Table 10, } \\
\text { Question 9) }\end{array}$ & -7 & 4 \\
\hline
\end{tabular}

Table 16 can be applied to either method of aerial refueling, and it is noted that the experienced flow rates of either probe-anddrogue or boom-receptacle aerial refueling under perform the expected flow rates. Fighter pilots refueling with a probe-and-drogue system experienced flow rates $44 \%$ to $58 \%$ slower than the referenced flow rates. Fighter pilots refueling with boom-receptacle systems experienced flow rates $27 \%$ to $45 \%$ slower than the referenced flow rates. The aerial refueling wing rates are even further off of the referenced flow rates.

It is also noticed that boom-receptacle method of aerial refueling is faster than the probe-and-drogue method of aerial refueling per ship. The fighter pilots who performed boomreceptacle aerial refueling experienced flow rates $31 \%$ faster than pilots who performed probe-and-drogue aerial refueling. Similarly, aerial refueling wings experienced flow rates $54 \%$ to $63 \%$ faster with the boom-receptacle method.

The second two questions (Question 3 and Question 4) proposed for this study concern the weight and volume impact for each method of aerial refueling. No hard evidence was gathered to show what the weight and volume impact is, largely because the information is company proprietary and each system varies greatly. Probes have many options for incorporation into aircraft from stationary probes like those attached to the A-4 Skyhawk to retractable probes like those attached to the F-18 Hornet to articulating probes like those on the S-3 Viking. Slipways also have varied placements from the nose of the aircraft like on the A-10 Thunderbolt to the shoulder as on the F-15 Eagle to the back as on the F-16 Fighting Falcon. The varied placement of the slipways is accompanied with varying amounts of plumbing required to reach a tank, wherever the tank may be placed in the aircraft. Another question that needs to be addressed in consideration of an aerial refueling system is what the system would displace. In some cases electronics could be placed where the refueling system is located while in other cases fuel may be displaced for the refueling system. There is no one answer for either of the questions concerning the weight and volume impact to an aircraft.

The last two questions (Question 5 and Question 6) proposed for this study concern safety and reliability for each method of aerial refueling. As seen in Table 4 and Table 5, some problems are common among both types of aerial refueling. For example; the performance of the tanker pumps, the connection between tanker and receiver, and FOD. There are some problems unique to probe-and-drogue refueling. Some of these unique problems include having a probe or probe tip snap off, and reel response (a BDA has no reel response).

From Table 6, the fighter pilots estimate that $1.7 \%$ of probe-and-drogue refueling operations have a refueling incident that causes a mission change. Fighter pilots, who flew boomreceptacle refueling, estimate that $3.2 \%$ of the refueling operations have an incident that causes a mission change. From the fighter pilot's point of view, boom-receptacle aerial refueling operations are almost twice as likely to have some refueling incident happen that would cause a mission change. From Table 8, 5 of 7 pilots that have flown both methods of aerial refueling prefer the boom-receptacle method of aerial refueling. 
From Table 11, the aerial refueling wings estimate that $2 \%$ of boom-receptacle operations foul the receiver or tanker and more than three times that number $(7.2 \%)$ of probe-and-drogue operations do. The aerial refueling wings estimate that $2 \%$ of boom-receptacle operations have a mechanical failure and slightly more $(3.3 \%)$ of probe-and-drogue operations do. When asked for a preference, all aerial refueling wings preferred the boom-receptacle method for safety and reliability.

Fighter pilots estimate that probe-anddrogue aerial refueling is safer and/or more reliable but they prefer the boom-receptacle method of aerial refueling. Aerial refueling wings estimate that the boom-receptacle method is safer and more reliable and they prefer the boom-receptacle method. While no definite conclusion can be formed from the above information, the issue of safety and reliability is a definite concern to both fighter pilots and aerial refueling wings.

With the coming age of unmanned combat aerial vehicles (UCAV), a consideration of which method of aerial refueling is best for the aircraft must be made. Can a UCAV refuel with either method? Would the UCAV fly as part of a fighter unit? Would the UCAV serve both the USAF and the USN? All are questions that affect how fighter aircraft refuel in the future.

\section{RECOMMENDATIONS}

It first needs to be stated that neither the boom-receptacle nor the probe-and-drogue methods of aerial refueling will ever be eliminated altogether. Probe-and-drogue aerial refueling will always be required to refuel helicopters and other aircraft on which a receptacle would not be feasible. The rotors on the helicopter would not allow a path for a boom to reach a receptacle, therefore there must be a probe extended beyond the rotors in order to refuel. Boom-receptacle aerial refueling will always be required to refuel large cargo aircraft and other large body aircraft on which a probe would not be feasible. These aircraft are too large to be able to maneuver a probe into a drogue, the aircraft would not be able to utilize multi-port due to their large wingspan, and the flow rates would not be sufficient.
It is recommended that a requirement of any new tanker design incorporate multi-port boom-receptacle aerial refueling. There is a benefit to multi-port and with the higher flow rates of boom-receptacle aerial refueling, formations of fighter aircraft would be able to refuel much faster with less turbulence. Drogues should also be incorporated in the designs of a new tanker since there are many probe equipped aircraft that will always require drogues.

The Air Force should increase its support of Navy aircraft with multi-port capability in order to reduce or eliminate the need for buddy-store and reduce or eliminate the need for multiple tankers while supporting U.S. Navy operations. Without this support, the USN will always require buddy-store and the function of Navy tactical aircraft will be reduced. This would also increase the interoperability of tanker aircraft.

There should be a considerable effort to eliminate BDAs and replace them with wing mounted pods. The BDA is the most dangerous prospect for probe-and-drogue aerial refueling since it has no reel response and it negates the tanker's ability to utilize boom-receptacle refueling until the BDA is removed.

Aerial refueling wings should monitor refueling rates and insure that aircraft are being refueled in a timely manner. From the results, aircraft are being refueled at rates much lower than expected or at rates lower than the equipment can optimally deliver. 


\section{REFERENCES}

Boeing KC-135 Stratotanker. (March 19, 2006). Retrieved March 27, 2006, from http://en.wikipedia.org/wiki/Boeing_KC-135_Stratotanker.

Bolkcom, C., \& Klaus, J. D. (2005 May 11). Air Force refueling methods: Flying boom versus hoseand-drogue. Washington, DC: Congressional Research Service (CRS) Report for Congress.

Byrd, V. B. (1994). Passing gas: The history of in-flight refueling. Chico, CA: Byrd Publishing Company.

Davis, L. (1986). Wild weasel, the SAM suppression story. Carrollton, TX: Squadron/Signal Publications, Inc.

Department of Defense. (1998, October 30). Joint Services Specification Guide: Air Vehicle Subsystems (DoD Publication No. JSSG-2009). Wright-Patterson AFB, OH: ASC/ENFA.

Drendel, L. (1986). Modern military aircraft: Thud. Carrollton, TX: Squadron/Signal Publications, Inc.

Gebicke, M. E. (1993a, July 19). Aerial refueling initiative: Cross-service analysis needed to determine best approach. Washington, DC: United States General Accounting Office.

Gebicke, M. E. (1993b, November 15). Operation desert storm: An assessment of aerial refueling operational efficiency. Washington, DC: United States General Accounting Office.

Holder, B., \& Wallace, M. (2000). Range unlimited: A history of aerial refueling. Atglen, PA: Schiffer Publishing Ltd.

Hopkins, R. S. (1997). Boeing KC-135 Stratotanker. Leicester, England: Midland Publishing Ltd.

Jenkins, D. R. (2002). Grumman A-6 Intruder. North Branch, MN: Specialty Press Publishers and Wholesalers.

Killingsworth, P. S. (1996). Multipoint aerial refueling: A review and assessment. Santa Monica, CA: RAND.

Naval Air Training and Operational Procedures Standardization Program. (1985, July 15). Air Refueling Manual (NAVAIR Publication No. 00-80T-110). Washington, DC: U.S. Government Printing Office.

Parker Aerospace. (2004). Aerial refueling equipment. Irvine, CA: Retrieved September 15, 2004, from http://www.parker.com/ag/AFD/pdf/af_aerial_refueling.pdf.

RAND Mission. (2005). Retrieved October 30, 2005, from http://www.rand.org/about/history

Reed, C. (1999). Lockheed C-130 Hercules and its variants. Atglen, PA: Schiffer Publishing Ltd.

Sargent Fletcher. (2001). ART/S pod. El Monte, CA. Retrieved June 23, 2005, from http://www.sargentfletcher.com/bus_dev/flyer_arts.pdf.

Sargent Fletcher. (2005). Retrieved December 5, 2005, from http://www.sargentfletcher.com/ars_charact.htm.

Smith, R. K. (1998). Seventy-five years of in-flight refueling: Highlights, 1923-1998. Retrieved May 31, 2004, from http://www.airforcehistory.hq.af.mil/Publications/ fulltext/75yrs_inflight_refueling.pdf, 41.

Steffen, A. A. C. (1998). McDonnell Douglas DC-10 and KC-10 extender. Leicester, England: Midland Publishing Ltd. 
U.S. Air Force fact sheet: KC-10 extender. (2003, October). Retrieved May 27, 2004, from http://www.af.mil/factsheets/factsheet.asp?fsID=109

U.S. Air Force fact sheet: KC-135 stratotanker. (2004, April). Retrieved May 27, 2004, from http://www.af.mil/factsheets/factsheet.asp?fsID $=110$

United States Marine Corps fact file: KC-130 Hercules. (1995, December). Retrieved June 14, 2004, from http://www.hqmc.usmc.mil/factfile.nsf/7e931335d515626a8525628100676e0c/ 0992276ba1b2f2b68525626e00494022? OpenDocument 
APPENDIX A - List Of Aerial Refueling Wings And Groups

\begin{tabular}{|c|c|c|}
\hline Address & Phone & FAX / Email \\
\hline $\begin{array}{l}\text { 107th ARW } \\
\text { Niagara Falls International Airport } \\
\text { Niagara Falls, NY } 14304\end{array}$ & (716) $236-2458$ & \\
\hline $\begin{array}{l}\text { 108CF/SCBI(FOIA) } \\
\text { 3324 Charles Blvd } \\
\text { McGuire AFB, NJ } 08641 \\
\end{array}$ & (609) 754-5806 & (609) 754-6158 \\
\hline $\begin{array}{l}\text { 121st ARW/PA } \\
7370 \text { Minuteman Way } \\
\text { Columbus, OH } 43217-5875\end{array}$ & (614) 492-4357 & $\begin{array}{l}\text { (614) 492-4215 } \\
\text { help@ohcolu.ang.af.mil }\end{array}$ \\
\hline $\begin{array}{l}\text { 128th Air Refueling Wing } \\
\text { Attn: FOIA Office } \\
1835 \text { East Grange Avenue } \\
\text { Milwaukee, WI 53207-6142 }\end{array}$ & (414) 944-8782 & foia@wimilw.ang.af.mil \\
\hline $\begin{array}{l}141 \text { st Air Refueling Wing } \\
1403 \text { W. Wainwright Blvd. } \\
\text { Fairchild AFB, WA 99011-99410 }\end{array}$ & (509) 247-7042 & \\
\hline $\begin{array}{l}\text { 186th ARW/SCIM (FOIA) } \\
\text { 6225 M Street, Bldg 603 } \\
\text { Meridian, MS 39307-7112 }\end{array}$ & (601) 484-9266 & (601) 484-9219 \\
\hline $\begin{array}{l}\text { 19th ARG } \\
225 \text { Beale Dr. } \\
\text { Robbins AFB, GA 31098-2700 }\end{array}$ & (478) $327-2958$ & \\
\hline $\begin{array}{l}22 \text { CS/SCXIR } \\
53298 \text { Kansas St, Ste } 5 \\
\text { McConnell AFB, KS 67221-7701 }\end{array}$ & (316) 759-3141 & christelle.meyer@mcconnell.af.mil \\
\hline $\begin{array}{l}\text { 319th Air Refueling Wing } \\
375 \text { Steen Blvd., Rm } 102 \\
\text { Grand Forks AFB, ND 58205-6015 }\end{array}$ & (701) 747-5023 & publicaffairs@grandforks.af.mil \\
\hline $\begin{array}{l}434 \mathrm{CS} / \mathrm{SCBK} \\
\text { Freedom of Information Act Office } \\
\text { Bldg } 100 \\
\text { Grissom ARB, IN } 46971\end{array}$ & (765) 688-2362 & $\begin{array}{l}\text { (765) 688-2362 } \\
\text { 434arw.pa@grissom.af.mil }\end{array}$ \\
\hline $\begin{array}{l}\text { 459th ARW } \\
3755 \text { Patrick Avenue } \\
\text { Andrews AFB MD } 20672 \\
\end{array}$ & (240) 857-6873 & \\
\hline $\begin{array}{l}\text { 916th ARW } \\
1195 \text { Blakeslee Ave. } \\
\text { Seymour Johnson AFB, NC 27531- } \\
2203\end{array}$ & (919) 722-2230 & (919) 722-2239 \\
\hline $\begin{array}{l}\text { 92nd Air Refueling Wing } \\
1 \text { E. Bong St. Suite 117A } \\
\text { Fairchild AFB, WA 99011-9588 }\end{array}$ & (509)247-2312 & 92arw.pa@fairchild.af.mil \\
\hline $\begin{array}{l}927 \text { ARW } \\
\text { 43087 Lake St. } \\
\text { Sang, MI } 48045\end{array}$ & (586) $307-5575$ & 927arw.pa@selfridge.af.mil \\
\hline $\begin{array}{l}940 \mathrm{CF} / \mathrm{SCB} \\
19395 \text { Edison Avenue Bldg. } 11606 \\
\text { Beale AFB, CA 95903-1215 }\end{array}$ & (530) 634-1838 & $\begin{array}{l}\text { (530)634-1864 } \\
\text { 940arw.pa@beale.af.mil }\end{array}$ \\
\hline
\end{tabular}




\section{APPENDIX B}

\section{Fighter Pilot Survey}

1. What type of aircraft have you flown, how many hours per aircraft and what method of aerial refueling was performed in each aircraft?

2. Approximate number of aerial refuelings in each aircraft.Training | Deployments | Combat

3. Describe any incidents that occurred during aerial refueling.

4. Approximate number of times there was a mission change due to an aerial refueling incidence.

5. Estimate the average time required for 4 ships to receive a normal off load for each aircraft type flown.

6. Approximate percentage of refueling operations that were multi-port.

7. Were you trained in the use of "quick flow"? How many times have you used this?

8. How many times have you refueled from the probe \& drogue "buddy store" system?

9. Which method of aerial refueling do you prefer (probe \& drogue or boom-receptacle) and why?

10. Any additional comments about aerial refueling that may aid in my research?

\section{APPENDIX C}

\section{Aerial Refueling Wing Survey}

This questionnaire is concerned with fighter receiver aircraft only unless otherwise noted.

P-D $=$ Probe and Drogue refueling system

$\mathbf{B}-\mathbf{R}=$ Boom Receptacle refueling system

\section{Refueling Averages}

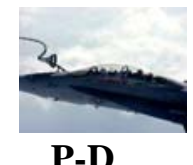

P-D

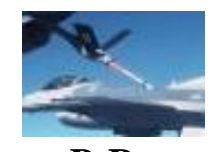

B-R

1. Average time for an aircraft to line up (seconds):

2. Average time to hook up (seconds):

3. Average time to transfer fuel (seconds):

4. Average time to disconnect (seconds):

5. Average time to clear (seconds):

6. Average number of aircraft refueled:

7. Average time for refueling mission (minutes):

8. Average number of missions per flight:

9. Average fuel flow rate (lbs/min):

10. Average amount of fuel transferred (lbs):

\section{Reliability \& Safety}

11. Percentage of refuelings that foul tanker or receiver system:

12. Percentage of refuelings that have a mechanical failure: 


\section{Aerial Refueling Wing Survey (Continued)}

$\mathbf{P}-\mathbf{D}=$ Probe and Drogue refueling system

B-R $=$ Boom Receptacle refueling system

\section{Other}

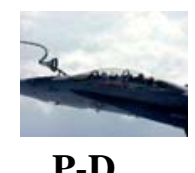

P-D

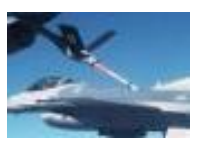

B-R

13. What percentage of missions refuel helicopters (or other probe mandatory aircraft) before or after fighters?

14. What percentage of missions refuel cargo (or other receptacle mandatory aircraft) before or after fighters?

15. What percentage of missions are multi-port?

\section{Preferred System}

16. Which system is faster?

17. Which system is safer?

18. Which system is more reliable?

\section{Safety or Reliability Concerns}

19. What are your safety or reliability concerns with the boom-receptacle method of aerial refueling?

20. What are your safety or reliability concerns with the probe-and-drogue method of aerial refueling? 